\title{
PEMAKNAAN PERUBAHAN PUSKESMAS X MENUJU BADAN LAYANAN UMUM DAERAH (BLUD) DALAM ASPEK LAYANAN DAN AKUNTANSI
}

\author{
Rizda Yuritsuni Firdausi \\ Sri Pujiningsih \\ Universitas Negeri Malang \\ rizdayuritsuni@gmail.com
}

\begin{abstract}
This research aims to understand the giving of meaning by the actors in Puskesmas $\mathrm{X}$ about Puskesmas X's organizational change towards BLUD viewed from the aspect of service and accounting. This research is a phenomenology using case study as the research strategy. This research took place in Puskesmas X. The research data were generated from interviewing the research informants. The research informants are The Head of Puskesmas X, Puskesmas X's chamberlains, and medical staff. The results of this research show that the Puskesmas X's actors who indirectly participate in making financial reports tend to accept BLUD, while the actors who directly participate in making financial reports tend to resist BLUD.
\end{abstract}

Keywords:

Puskesmas; BLUD; Akuntansi; Fenomenologi

Pembentukan Badan Layanan Umum (BLU) atau Badan Layanan Umum Daerah (BLUD) di pemerintahan dapat dilakukan dengan dua cara, yaitu dengan mendirikan instansi pemerintahan baru berlabel BLU/ BLUD atau merubah instansi pemerintahan yang ada menjadi BLU/ BLUD. Instansi pemerintah yang akan menjadi BLU/ (BLUD) akan mengalami perubahan organisasional, yang berarti mengubah secara struktur, kewenangan, lingkungan, norma, dan perilaku (Prakoso, 2014: 7). Tidak hanya itu, instansi pemerintah yang menjadi BLU/BLUD mengalami perubahan manajerial yang sangat mendasar seperti kinerja pelayanan, profesionalisme, akuntabilitas, dan transparansi (Prakoso, 2014: 7).

Perubahan pada kinerja pelayanan dan profesionalisme berarti mengubah bagaimana cara instansi pemerintahan meningkatkan pelayanan kepada masyarakat. Perubahan dalam hal tersebut berdampak langsung pada banyak pihak dan manfaatnya dapat dirasakan langsung. Sedangkan perubahan pada akuntabilitas dan transparansi berarti mengubah sistem perakuntansian instansi tersebut. Perubahan sistem perakuntansian berdampak langsung pada pihak-pihak tertentu, khususnya pihak yang berurusan langsung dengan pengelolaan keuangan, tetapi manfaat dari perubahan ini tidak dapat dirasakan langsung oleh masyarakat, termasuk oleh para aktor. Perubahan ke arah BLUD beserta dampak dan manfaatnya dapat membentuk pola pikir aktor-aktor pada suatu instansi pemerintahan dalam melihat serta memaknai perubahan tersebut.

Terkait perubahan pelayanan, BLUD menghendaki adanya peningkatan pelayanan dengan berubahnya status suatu instansi pemerintahan menjadi BLUD. Perubahan pelayanan merupakan bagian yang mutlak dalam perubahan suatu instansi menjasi BLUD. Oleh sebab itu, perubahan dan atau peningkatan pelayanan hendaknya dimaknai secara positif.

Dalam hal akuntansi keuangan, BLUD memberikan keleluasan pengelolaan keuangan dan memberlakukan penggunaan anggaran berbasis kinerja serta sistem akuntansi berbasis akrual daripada penggunaan anggaran berbasis kas. Hal ini menjadikan perubahan anggaran dan sistem akuntansi menuju basis akrual masuk dalam bagian perubahan suatu instansi menjadi BLUD. Penggunaan anggaran berbasis kinerja dan sistem akuntansi berbasis akrual bertujuan untuk akuntabilitas dana dan transparansi penggunaan dana secara lebih baik. Oleh sebab itu, perubahan 
penggunaan anggaran tradisional dan sistem akuntansi berbasis kas menjadi penggunaan anggaran berbasis kinerja dan sistem akuntansi berbasis akrual seyogyanya dimaknai pula secara positif.

Berdasarkan uraian di atas dapat dikatakan bahwa perubahan sebuah instansi pemerintah menjadi BLUD seyogyanya dimaknani secara positif, baik pada aspek perubahan pelayanan maupun pada aspek perubahan akuntansinya. Akan tetapi, sejauh ini belum diketahui bagaimana para aktor perubahan pada instansi BLUD menanggapinya. Untuk itu penelitian ini bermaksud mengetahui bagaimana para aktor memaknai perubahan yang melekat pada BLUD. Penelitian tentang pemaknaan perubahan BLUD dalam lingkup Pusat Kesehatan Masyarakat (Puskesmas) ini diharapkan menjadi upaya rintisan ke arah tersebut.

Unit Pelaksana Teknis Dinas (UPTD) Puskesmas merupakan instansi pemerintah daerah berbentuk unit kerja yang menjalankan tugas pokok dan fungsi memberikan pelayanan kesehatan kepada masyarakat, khususnya masyarakat kelas menengah ke bawah. UPTD Puskesmas belakangan ini dituntut untuk meningkatkan pelayanannya kepada masyarakat, seperti membuka layanan 24 jam penuh (Anugrah, 2016), dan memberikan pelayanan BPJS kepada masyarakat (Jamsosindonesia.com, diakses 30 September 2016). Untuk meningkatkan pelayanannya tersebut UPTD Puskesmas terhambat masalah mekanisme pengelolaan keuangan yang kurang fleksibel.

Puskesmas merupakan UPTD di bawah Dinas Kesehatan sehingga pengelolaan keuangan Puskesmas mengikuti ketentuan pengelolaan keuangan negara pada umumnya (Jamsosindonesia.com, diakses 30 September 2016). Pembiayaan operasional UPTD Puskesmas berasal dari APBD (Bagian Hukum Pemerintah Kabupaten Malang, Peraturan Bupati Malang No 7 Tahun 2009 tentang UPTD Puskesmas pada Dinas Kesehatan Kabupaten Malang). Dana yang ditarik dari masyarakat atas pelayanan yang diberikan, tidak dapat dipakai langsung untuk operasional karena harus disetorkan terlebih dahulu ke kas daerah (Purmono, 2010). Dana tersebut dialokasikan kembali ke Puskesmas setelah melalui proses penganggaran dan pencairan. Tidak hanya masalah mekanisme pengelolaan keuangan yang kurang fleksibel, palayanan obat di UPTD Puskesmas juga terbatas karena UPTD Puskesmas tidak bisa mengadakan obat-obatan secara mandiri. UPTD Puskesmas pun terkadang terkendala kurangnya tenaga ahli medis.

Pembaharuan atau reformasi di UPTD Puskesmas dengan mengubahnya menjadi Badan Layanan Umum Daerah (BLUD) dirasa pemerintah daerah sangat diperlukan agar UPTD Puskesmas dapat meningkatkan fungsi pelayanannya kepada masyarakat. Pemerintah Kabupaten Malang sendiri menargetkan 39 UPTD Puskesmas yang dimilikinya menjadi BLUD (Surabaya.bisnis.com, diakses 2 Oktober 2016), meskipun yang terealisasi baru 10 di tahun ini. Dua puluh sembilan UPTD Puskesmas lainnya direncanakan akan segera menyusul menjadi BLUD. UPTD Puskesmas X merupakan satu di antara sembilan belas UPTD Puskesmas yang belum menjadi BLUD dan ditargetkan oleh Pemerintah Kabupaten Malang untuk menjadi BLUD tahun 2017. Akan tetapi, Kepala Puskesmas X menuturkan pada peneliti bahwa UPTD Puskesmas $\mathrm{X}$ merasa belum siap untuk menerapkan pola pengelolaan BLUD, padahal UPTD Puskesmas X, jika ditinjau dari aspek operasional dan teknis dapat dikatakan sudah siap.

Penelitian tentang BLUD sudah banyak dilakukan sebelumnya, sebagai contoh, tiga penelitian yang erat sekali kaitannya dengan penelitian ini, yaitu penelitian yang dilakukan oleh Rondonuwu \& Trisnantoro (2013), Ariyati, dkk (2016), dan Anggraeny (2013). Penelitian Rondonuwu \& Trisnantoro terkait dengan Manajemen Perubahan di Lembaga Pemerintah (Studi Kasus Implementasi Kebijakan PPK-BLUD di RSJ Provinsi Nusa Tenggara Barat. Hasil studi kasus ini menenunjukkan bahwapelaksanaan proses transformasi menuju implementasi kebijakan PPK-BLUD belum berjalan sesuai yang diharapkan, Dalam hal ini, pola keuangan BLUD belum dapat dilaksanakan karena para pengelola keuangan masih ragu-ragu untuk menerapkan.

Penelitian Ariyati, dkk (2016) tentang Penerapan Standar Akuntansi Keuangan (SAK) dan Standar Akuntansi Pemerintahan (SAP) pada Sistem Akuntansi Badan Layanan Umum (BLU) Universitas juga menggunakan rancangan penelitian studi kasus. Hasilnya menunjukkan bahwa sistem akuntansi pada BLU Universitas $X$ sebagian besar merujuk kepada PMK No.76/PMK.05/2008, Standar Akuntansi Keuangan (SAK), dan Standar Akuntansi Pemerintahan 
(SAP), meskipun ada hal-hal yang tidak sejalan dengan ketiga aturan tersebut karena beberapa hambatan seperti proses implementasi yang tidak sepenuhnya sesuai peraturan dan sumber daya yang tidak memadai.

Penelitian Anggraeny (2013) yang berjudul Inovasi Pelayanan Kesehatan dalam Meningkatkan Kualitas Pelayanan di Puskesmas Jagir Surabaya menggunakan rancangan penelitian kualitatif. Hasil penelitian tersebut menunjukkan bahwa inovasi dalam hal pelayanan yang dilakukan Puskesmas Jagir terdiri dari inovasi jasa pelayanan dan inovasi proses.

Sejauh yang diketahui peneliti, belum pernah ada penelitian yang mengkaji tentang pemaknaan perubahan Puskesmas menuju BLUD oleh aktor-aktor Puskesmas ditinjau dari aspek perubahan pelayanan dan akuntansinya. Oleh karena itu, peneliti termotivasi untuk mengangkat penelitian tersebut.

\section{METODE}

Penelitian merupakan jenis penelitian kualitatif dengan pendekatan fenomenologi. Untuk menjawab fokus atau permasalahan penelitian tentang pemaknaan, maka penelitian ini menggunakan fenomenologi. Penelitian fenomenologi adalah penelitian yang bertujuan untuk memahami pemaknaan aktor atas fenomena penelitian (Kuswarno, 2009). Peneliti menggunakan studi kasus sebagai strategi penelitian (Yin, 1994). Hal ini dimaksudkan untuk memberikan fleksibilitas peneliti dalam pengumpulan data yang lebih mendalam. Peneliti bertindak sebagai human instrument. Penelitian dilakukan di Puskesmas X yang terletak di salah satu kecamatan di selatan Kabupaten Malang. Data penelitian ini adalah data primer yang diperoleh melalui wawancara dengan beberapa informan antara lain Kepala Puskesmas X, bendahara-bendahara Puskesmas X, dan tenaga medis. Data dianalisis dengan menggunakan model Miles \& Huberman (dalam Sugiyono, 2010) yang terdiri dari reduksi data, penyajian data, dan verifikasi data. Analisis data dilakukan dengan melalui tematisasi data. Temuan yang di dapat selama proses penelitian akan diuji keabsahannya dengan peningkatkan ketekunan.

\section{HASIL DAN PEMBAHASAN}

\section{Pemaknaan Perubahan Puskesmas X Menuju BLUD oleh Aktor Puskesmas X a. Inovasi Pelayanan sebagai Makna Perubahan}

Prakoso (2014) menyatakan bahwa perubahan organisasi sektor publik menjadi BLUD akan mengubah kinerja pelayanan dan profesionalisme organisasi sektor publik terkait. Arah perubahan yang diharapkan tentunya menuju pelayanan yang lebih baik. Sementara itu, Hansen (2009) menyatakan bahwa perubahan sektor publik ditandai dengan adanya inovasi yang biasanya dihubungkan dengan New Public Management (NPM). Puskesmas X akan mengalami perubahan pada kinerja pelayanan dan profesionalisme mereka dalam menyampaikan/memberikan pelayanan kesehatan kepada masyarakat dengan menggunakan praktik manajemen sektor swasta. Inovasi merupakan salah satu praktik manajemen yang digunakan oleh organisasi sektor swasta. Inovasi pelayanan kesehatan merupakan suatu keharusan bagi Puskesmas ketika sudah menjadi BLUD karena telah diberi kemudahan pengelolaan keuangan yang ditunjukkan oleh pernyataan "Jadi memang inovasi itu harus ada kalau mau BLUD ..” (BL. 7) dan pernyataan berikut ini.

“...nanti kalau sudah jadi BLUD kan kita dapat mengelola sendiri keuangan kita, nah dengan flesksibilitas tersebut kita harus bisa berinovasi. Tidak ada lagi alasan untuk tidak berinovasi karena sudah tidak ada halangan seperti menunggu dana cair dan setor menyetor uang...." (BL. 9)

Oleh karena itu, perubahan dalam bidang pelayanan sebagai bagian dari perubahan menjadi BLUD harus tampak pada pelayanan yang inovatif. 
Rogers (dalam Sahin, 2006) mendefinisikan inovasi sebagai suatu ide, gagasan, praktik, objek/benda yang disadari dan diterima sebagai suatu hal yang baru oleh individu atau unit yang mengadopsinya. Menurut Direktorat Inovasi dan Inkubator Bisnis Universitas Indonesia (2016), inovasi dapat berupa: a) hal yang benar-benar baru, b) hal yang telah melalui peningkatan yang signifikan, c) hal yang dikembangkan pertama kali oleh suatu perusahaan atau organisasi, dan d) hal yang diadopsi dari perusahaan atau organisasi lain. Dari kedua pernyataan di atas dapat disimpulkan bahwa individu atau unit/organisasi dalam berinovasi tidak selalu harus menciptakan sesuatu yang benar-benar baru, tetapi individu atau unit/organisasi dapat mengadopsi ide/gagasan/praktik/objek/benda yang menurutnya adalah hal baru.

Seperti yang telah dijelaskan sebelumnya, BLUD berdampak pada perubahan kinerja pelayanan dan profesionalisme Puskesmas X dalam memberikan pelayanannya kepada masyarakat yang harus tampak pada pelayanan kesehatan yang inovatif. Pada konteks penelitian ini, dampak BLUD pada kinerja pelayanan dan profesionalisme tersebut sudah menunjukkan upaya perintisan/persiapan ke arah yang diharapkan. Artinya, sudah ada upaya perubahan pada kinerja pelayanan dan profesionalisme Puskesmas $\mathrm{X}$ dalam memberikan pelayanan kepada masyarakat. Hal ini terlihat dari komputerisasi pelayanan dengan bantuan software E-medika yang sedang diterapkan di Puskesmas X.

Menggunakan E-medika, pendaftaran pasien untuk berobat menjadi terotomatisasi dan dilakukan sendiri oleh pasien (bukan oleh pegawai) melalui scan kartu peserta/scan sidik jari/short message service (SMS) dengan tujuan untuk mempercepat pelayanan. E-medika juga mengintegrasikan pelayanan di Puskesmas mulai dari pendaftaran pasien, pelayanan di poli, pelayanan di kasir, dan pelayanan di apotik. Sistem tersebut juga secara otomatis menyimpan data rekam medis dan keuangan, serta dapat mengolah data rekam medis dan keuangan menjadi laporan kesehatan dan laporan keuangan.

Apabila diklasifikasikan ke dalam tipe-tipe inovasi menurut Damanpour (1991dalam Fonseca, 2014), maka komputerisasi pelayanan termasuk ke dalam inovasi proses, yaitu inovasi yang memiliki ciri-ciri berfokus pada efisiensi yang ingin dicapai. Sementara itu, Anggraeny (2013) menuliskan bahwa inovasi proses, dalam kaitannya dengan pelayanan publik, merupakan inovasi yang berfokus pada peningkatan kualitas pelayanan publik. Puskesmas X menerapkan komputerisasi pelayanan bertujuan untuk efisiensi pelayanan dan sekaligus peningkatan kualitas pelayanan. Hal ini terbaca dari pernyataan Kepala Puskesmas X berikut ini.

“...Kita mempercepat pelayanan dengan sistem komputer. Kemudian sistem self service. Kemudian sistem sms saja mereka daftarnya. Gitu. Hanya untuk mempercepat saja pelayanannya. Mudah-mudahan dengan cepatnya pelayanan, masyarakat puas akan pelayanan kita, dan tentunya mereka akan datang kembali ke sini.” (BL. 16)

Selain inovasi proses, jenis inovasi lainnya menurut Damanpour (1991) adalah inovasi produk atau jasa. Puskesmas $\mathrm{X}$ belum ada upaya untuk mengembangkan inovasi produk atau jasa saat ini. Akan tetapi, Puskesmas X memiliki niatan untuk mengembangkan inovasi produk atau jasa di bidang pelayanan kesehatan. Niatan ini terlihat dari pernyataan berikut.

"Belum itu mbak, kita belum memikirkan yang itu. Kita selesaikan yang ini (akreditasi) dulu sampai benar-benar tuntas. Baru setelah itu nanti puskesmas akan merundingkan akan mengembangkan inovasi pelayanan kesehatan yang seperti apa. Kan harus survey dulu ke pasien, itu kan butuh waktu dan tenaga”. (BL. 10)

Pernyataan tersebut sekaligus menjelaskan bahwa pengembangan inovasi produk/jasa pelayanan kesehatan diawali dengan melakukan survey kebutuhan pasien akan pelayanan kesehatan. Dengan demikian dapat juga diartikan bahwa pengembangan inovasi produk atau jasa pelayanan kesehatan mempertimbangkan masukan dari masyarakat (pasien) sebagai pelanggan jasa pelayanan kesehatan Puskesmas X. Kepala Puskesmas X menegaskan kembali pentingnya masukan pasien untuk pengembangan inovasi pada pernyataan berikut 
“..setiap jenis pelayanan yang kita kembangkan itu benar-benar harus menjadi kebutuhan masyarakat. Jadi masukan dari masyarakat, kemudian dari survey kebutuhan pelanggan, itu baru kemudian inovasi apa yang bisa kita kembangkan" (BL. 8).

Pengembangan inovasi produk/jasa pelayanan kesehatan dengan mempertimbangkan kebutuhan pasien membuktikan pernyataan Engström (2014) bahwa penyedia jasa pelayanan kesehatan dapat lebih patient centered dan efisien dengan mengubah peran pasien yang semula merupakan penerima jasa pasif menjadi partisipan yang lebih aktif dan kolaboratif. Engström (2014) juga menyatakan bahwa pada saat penyedia jasa pelayanan kesehatan melihat pasien sebagai mitra aktif dalam proses perawatan, maka penyedia jasa pelayanan kesehatan akan mengadopsi pandangan tentang penciptaan nilai yang biasanya digunakan dalam sektor privat.

Selain mempertimbangkan kebutuhan masyarakat (pasien) sebagai pelanggan, inovasi produk atau jasa pelayanan kesehatan yang akan dikembangkan Puskesmas X sebaiknya juga mempertimbangkan karakteristik Puskesmas X. Karakterisitik utama Puskesmas X adalah Puskesmas yang memiliki perhatian khusus pada kesehatan ibu dan anak. Karakteristik Puskesmas $\mathrm{X}$ sebagai Puskesmas yang memiliki perhatian khusus pada kesehatan ibu dan anak terbaca dari slogannya "Pembinaan Remaja Putri dan Cinta Ibu untuk Mencegah Kematian Ibu dan Bayi". Jadi, Puskesmas X dapat membuat inovasi jasa pelayanan kesehatan yang tidak hanya mementingkan kebutuhan masyarakat (pasien) sebagai pelanggan, tetapi juga mempertimbangkan karakteristik Puskesmas X sendiri, yaitu pelayanan kesehatan yang berfokus pada ibu dan anak. Hal ini perlu agar ada keterbaharuan dalam inovasi jasa pelayanan kesehatan yang mereka kembangkan.

Inovasi dalam bentuk produk atau jasa dapat digunakan perusahaan atau organisasi untuk menciptakan keunggulan kompetitif/keunggulan bersaing baginya (Sugiyarti, 2015). Dengan kata lain, inovasi dapat dikatakan sebagai alat bagi perusahaan atau organisasi untuk bersaing. Hood (1991: 4-5) dengan teori NPM yang diusungnya mengajarkan organisasi sektor publik untuk beralih ke kompetisi yang lebih besar, sementara Bojović (2006: 300) menyatakan bahwa organisasi sektor publik sebagai penyedia jasa publik berkompetisi dengan sesama organisasi sektor publik penyedia jasa, serta berkompetisi dengan organisasi swasta penyedia jasa yang sama. Maka dalam hal ini, BLUD sebagai organisasi sektor publik, menerapkan NPM. Sehubungan dengan pendapat-pendapat ahli tersebut, prinsip peralihan pada kompetisi yang lebih besar tampaknya hanya berlaku pada beberapa kasus tertentu di Puskesmas BLUD, sebagaimana dapat dilihat dari pernyataan Kepala Puskesmas berikut ini.

“.... Jadi sebenarnya gak ada "oh saya harus menyaingi puskesmas lain”, enggak begitu, tapi bagaimana puskesmas ini dioptimalkan ya agar masyarakat dalam satu kecamatan lah secara sederhananya itu puas dengan pelayanan kita. Ya kita tidak pernah berpikir lho bahwasanya harus lebih baik dari puskesmas itu karena kita udah punya wilayah masing-masing, satu kecamatan". (BL. 15)

Puskesmas X sebagai Fasilitas Kesehatan Tingkat Pertama (FKTP) apabila sudah menjadi BLUD tidak akan bersaing dengan FKTP lainnya dalam memperebutkan konsumen demi mendapatkan pendapatan yang besar karena masing-masing FKTP memiliki wilayah kerja sendiri. Dengan memiliki wilayah kerja sendiri-sendiri, FKTP memiliki kewajiban untuk melayani masyarakat yang terdaftar sebagai pasien BPJS di wilayahnya masing-masing. Masyarakat pengguna BPJS hanya dapat berobat di FKTP di mana ia terdaftar, kecuali ia tidak menggunakan BPJSnya atau menjadi pasien umum. Dengan kata lain, masing-masing FKTP sudah memiliki konsumen masing-masing, karena di setiap Puskesmas, anggaran dana kapitalisasi dianggarkan dengan berdasarkan jumlah pasien BPJS yang terdaftar. Persaingan justru diperkirakan akan terjadi antara Puskesmas BLUD dengan Fasilitas Kesehatan Tingkat Lanjut (FKTL) seperti Rumah Sakit, baik swasta maupun milik pemerintah karena perbedaan kualitas dan kelengkapan jasa pelayanan kesehatan.

Keunggulan bersaing yang dihasilkan dari inovasi dapat membawa nilai yang unggul dan keuntungan yang lebih besar bagi perusahaan atau organisasi (Zamalludin, 2006). Akan tetapi, 
berdasarkan pernyataan "Sebenarnya dikatakan persaingan, sebenarnya kita itu bukan bersaing untuk seperti mendapatkan finansial ya bukan, tapi bagaimana kita itu mengembangkan spesifikasi..." (BL. 15) dan “...Dengan pelayanan yang baik, kemudian inovasi yang baik, masyarakat akan terlayani dengan baik dan itu secara tidak langsung akan meningkatkan pendapatan puskesmas..." (BL. 1), inovasi yang dikembangkan Puskesmas BLUD tidak digunakan untuk mengejar pendapatan yang besar, melainkan untuk meningkatkan pelayanan kesehatan kepada masyarakat. Jadi, inovasi yang dikembangkan oleh Puskesmas BLUD tidak digunakan untuk mencari keuntungan finansial sebagaimana seharusnya sektor publik pada umumnya.

\section{b. Laporan yang Rumit sebagai Makna Perubahan}

Bagi instansi pemerintahan yang masih menggunakan praktik akuntansi tradisional, perubahan instansi pemerintahan menjadi Badan Layanan Umum Daerah juga diikuti dengan perubahan akuntabilitas dan transaparansi (Prakoso, 2014). Perubahan akuntabilitas dan transaparansi sebagai dampak dari perubahan instansi pemerintahan menjadi BLUD harus dapat dilihat dari perubahan sistem perakuntansian, yang semula berbasis kas menjadi berbasis akrual, serta penganggaran tradisional menjadi penganggaran berbasis kinerja. Akan tetapi, pada Puskesmas $\mathrm{X}$ belum ditemukan adanya upaya perintisan/persiapan menuju perubahan yang diharapkan dalam hal perakuntansian. Artinya, kondisi sistem perakuntansian Puskesmas X saat ini masih menggunakan praktik tradisional.

Kondisi perakuntansian Puskesmas $\mathrm{X}$ yang menggunakan praktik tradisional tersebut teridentifikasi dari pernyataan "...jadi untuk membuat target ya berarti itu satu tahun itu kita berpatokan dengan tahun-tahun yang sebelumnya...” (AK. 9), “...nanti itu Juni itu membuat anggaran (RKA) untuk tahun 2018, kita membuat dari puskemas sendiri. Trus asalnya dari mana, ya sesuai dengan pendapatan yang tahun yang sudah berlalu kemarin untuk patokan ya..." (AK. 9), dan "...Nah sering itu Dinas tanya ke saya "program iki kok metu maneh mbak?", ya saya jawab saja lek itu kan program dasare jadi ada lagi. Lek gak gitu ya tak jawab programe tahun lalu belum selesai" (AK. 10). Berdasarkan pernyataan-pernyataan di atas, anggaran yang digunakan Puskesmas X saat ini merupakan anggaran inkremental. Anggaran inkremental merupakan sistem penganggaran dengan menggunakan anggaran tahun sebelumnya sebagai dasar pembuatan anggaran, kemudian dilakukan perubahan kecil di dalamnya (Syarifuddin, 2003). Oleh sebab ciriciri tersebut, maka anggaran inkremental dikategorikan sebagai anggaran tradisional (Mardiasmo 2004).

Menurut Widyantoro (2009), kemunculan NPM mempengaruhi konsep anggaran suatu negara, yaitu memicu perubahan sistem anggaran dari anggaran tradisional menjadi anggaran yang lebih berorientasi kinerja. Oleh karena itu, BLUD sebagai perwujudan dari NPM di Indonesia menghendaki penggunaan anggaran berbasis kinerja (Permendagri No 61 Tahun Tahun 2007). Hal ini menyebabkan setiap instansi pemerintahan yang masih menggunakan anggaran inkremental, termasuk Puskesmas X, jika menjadi BLUD seharusnya wajib meninggalkan praktik penggunaan anggaran inkremental dan beralih ke penggunaan anggaran berbasis kinerja.

Anggaran yang berorientasi kinerja atau yang umum dikenal sebagai anggaran berbasis kinerja (performance based budgeting) secara prinsip menghubungkan pengeluaran negara dengan hasil yang ingin dicapai oleh pemerintah (output/outcome) (Sancoko dalam Widyantoro, 2009: 2). Artinya, penyusunan, pembahasan, penetapan sampai pengawasan pelaksanaan anggaran tidak cukup dengan hanya melihat besar kecilnya anggaran yang merupakan masukan, tapi juga harus memperhatikan kinerja anggaran tersebut yang meliputi capaian kinerja, keluaran, hasil dan manfaat serta tepat tidaknya kelompok sasaran kegiatan yang dibiayai anggaran tadi (Natsir dalam Kurrohman, 2013: 2). Maka dengan begitu setiap rupiah yang dikeluarkan jelas penggunaannya dan dapat dipertanggungjawabkan. Hal ini juga yang menjadi alasan dibalik BLUD mewajibkan penggunaan anggaran berbasis kinerja dibanding anggaran tradisional seperti anggaran inkremental.

Anggaran inkremental sebagai pendekatan anggaran yang digunakan oleh Puskesmas X saat ini, memang mudah dilakukan dan dapat dibuat dengan cepat karena menggunakan anggaran 
tahun sebelumnya yang diubah atau disesuaikan, tetapi anggaran ini memiliki beberapa kelemahan. Tiga kelemahan anggaran inkremental di antaranya adalah 1) kurang menekankan pada output yang hendak dicapai (Kurrohman, 2013), 2) mentransfer masalah-masalah tahun anggaran sebelumnya ke tahun anggaran berikutnya (Abdullahi dalam Adah dan Mamman, 2013), dan 3) kurang mendorong organisasi untuk membuat program atau acara baru untuk mengevaluasi sumber daya dari program yang ada (Budget Model Review Committee of Wisconsin University, 2014). Kelemahan kelemahan tersebut jelas bertentangan dengan prinsip BLUD yang menjunjung efisiensi, efektifitas, produktivitas.

Sementara itu, penggunaan anggaran berbasis kinerja pemerintahan daerah sudah ditetapkan melalui Undang-Undang Nomor 32 Tahun 2004 tentang Pengelolaan Keuangan Daerah dan Undang-Undang 33 Tahun 2004 tentang Perimbangan Keuangan Pusat dan Daerah (Rohmawati, 2015). Sesuai dengan aturan tersebut, Puskesmas X sebagai Unit Kerja di bawah Satuan Kerja Perangkat Daerah (Dinas Kesehatan Kabupaten Malang) seharusnya sudah menggunakan sistem anggaran berbasis kinerja. Akan tetapi, kenyataan dalam praktiknya, aturan tersebut belum diimplementasikan oleh Puskesmas X. Bahkan sampai penelitian dilakukan, peneliti belum menemukan adanya upaya yang dilakukan Puskesmas X untuk mengubah anggaran yang mereka gunakan.

Dengan berubahnya anggaran Puskesmas menjadi anggaran berbasis kinerja, dokumendokumen anggaran yang akan dibuat Puskesmas X nantinya akan sedikit berbeda tetapi tetap melalui alur yang sama. Puskesmas $X$ tidak lagi akan membuat Renstra dan Rencana Kerja Anggaran, melainkan membuat Rencana Strategi Bisnis dan Rencana Bisnis Anggaran. Perubahan tersebut bukan sekedar perubahan istilah, tetapi juga berimplikasi pada perubahan konten yang lebih menitikberatkan pada pengukuran kinerja. Rencana Strategi Bisnis berisi visi, misi, program strategis, pengukuran kinerja, rencana pencapaian lima tahunan, dan proyeksi keuangan lima tahunan (Permendagri No. 61 Tahun 2007). Rencana Bisnis Anggaran setidaknya berisi kinerja tahun berjalan, asumsi mikro dan makro, target kinerja, analisis dan perkiraan biaya satuan, perkiraan harga, anggaran pendapatan dan biaya, besaran presentase ambang batas, prognosa laporan keuangan, perkiraan maju, rencana pengeluaran investasi modal, dan ringkasan pendapatan dan biaya untuk keperluan konsolidasi dengan RKA-SKPD/RAPBD (Permendagri No. 61 Tahun 2007).

Selain anggaran, praktik akuntansi tradisional di Puskesmas X juga terlihat dari temuantemuan berikut ini.

1) Transaksi keuangan dicatat dan diakui oleh Puskesmas $X$ pada saat ada aliran kas masuk dan keluar yang teridentifikasi dari buku-buku keuangan yang mencatat transaksi-transaksi pada kolom "pemasukan" atau "pengeluaran".

2) Tidak diakuinya utang (beban yang masih harus dibayar) padahal Kepala Puskesmas dan Bendahara Umum mengakui bahwa biasanya ada beban/pengeluaran yang muncul sebelum dana kapitasi/dana operasional cair sebagaimana dalam pernyataan "....untuk tanggal tanggal seperti ini kita belum punya uang, jadi istilahe ngutang. Nah nanti tanggal 16 itu pencairan uang berarti nanti kita bayar uang,..." (AK, 11) dan "Boleh kita pembelian misalnya alat tulis di bla bla bla, tanggalnya misalnya tanggal 10 februari, nah nanti kita nyairkannya tanggal 20 . Maka lunas dibayarnya itu tanggal 20. Jadi istilah itu kita ngutang dulu." (AK. 11).

3) Laporan keuangan yang dibuat oleh Puskesmas $X$ bukan berbentuk laporan keuangan pada umumnya yang dibuat oleh perangkat daerah sebagai entitas akuntansi/entitas pelaporan (neraca, laporan realisasi anggaran, laporan arus kas, dan catatan atas laporan keuangan), melainkan hanya berupa buku-buku transaksi yang dilaporkan/disetorkan ke Kepala Puskesmas dan Dinas Kesehatan bersamaan dengan bukti transaksi dan surat pertanggungjawaban (SPJ). Puskesmas tidak membuat laporan keuangan sendiri karena masih satu kesatuan dengan Dinas Kesehatan Kabupaten Malang sehingga yang menyusun laporan keuangan adalah Dinas Kesehatan. Dari tiga temuan di atas, praktik akuntansi yang masih berlangsung sampai saat ini di Puskesmas $\mathrm{X}$ adalah akuntansi berbasis kas. 
Komponen utama dari NPM dibentuk oleh gagasan dan frasa akuntansi manajemen seperti efisiensi dan akuntabilitas untuk mengendalikan biaya, berorientasi pasar untuk memenuhi kebutuhan pasien, meminta pertanggungjawaban lembaga publik atas kinerja terukur mereka, dan semakin mendasarkan alokasi sumber daya pada kinerja (Malmmose, 2012). Dengan mengikuti agenda NPM, penerapan akuntansi akrual telah menjadi reformasi utama untuk meningkatkan akuntabilitas dan transparansi sektor publik (Hassan, 2013). NPM, seperti dijelaskan sebelumnya, merupakan konsep penerapan praktik-praktik manajemen sektor swasta pada sektor publik (Hood, 1991). Contoh penerapan praktik manajemen swasta pada sektor publik adalah penerapan akuntansi berbasis akrual yang digunakan sebagai alat untuk mengukur kinerja, pengendalian output, dan akuntabilitas oleh sektor swasta (Ibrahim, 2013). Oleh karena itu, BLUD sebagai bentuk penerapan NPM di Indonesia mengharuskan penggunaan akuntansi berbasis akrual (Permendagri No. 61 Tahun 2007).

Akuntansi berbasis akrual merupakan basis akuntansi dimana transaksi dan kejadian ekonomi lainnya dicatat dan diakui pada saat terjadi, bukan pada saat uang tunai atau setaranya diterima atau dibayar (Permendagri No. 64 Tahun 2013). Tujuan mengubah cara pelaporan keuangan ke akrual basis adalah membuat biaya sebenarnya yang dikeluarkan oleh pemerintah lebih transparan (Blöndal, 2003). Tujuan lainnya adalah memperbaiki pengambilan keputusan di pemerintahan dengan menggunakan informasi yang disempurnakan ini. Pengubahan sistem akuntansi berbasis kas menjadi akuntansi berbasis akrual menuntut manajer bertanggungjawab atas semua biaya yang terkait dengan hasil dan/atau keluaran yang dihasilkan, bukan hanya atas pengeluaran tunai langsung. Hanya akrual yang memungkinkan untuk menangkap biaya penuh ini, sehingga mendukung pengambilan keputusan yang efektif dan efisien oleh manajer.

Pemerintah sudah menetapkan penggunaan akuntansi berbasis akrual selambat-lambatnya tahun 2015 melalui PP No 64 Tahun 2013 tentang Standar Akuntansi Pemerintah Berbasis Akrual. Sementara itu, sistem akuntansi yang digunakan oleh Pemerintah Daerah Kabupaten Malang saat ini masih akuntansi berbasis kas menuju akrual, dimana pendapatan, belanja, dan pembiayaan diakui berbasis kas, sedangkan aset, utang, dan ekuitas diakui berbasis akrual (Peraturan Bupati Malang No. 13 Tahun 2014). Sesuai dengan aturan tersebut, Puskesmas X sebagai Unit Kerja di bawah Satuan Kerja Perangkat Daerah (Dinas Kesehatan Kabupaten Malang) seharusnya sudah menggunakan sistem akuntansi berbasis akrual atau setidaknya telah menggunakan sistem akuntansi berbasis kas menuju akrual. Akan tetapi, kenyataan dalam praktiknya aturan tersebut belum diimplementasikan oleh Puskesmas X. Bahkan sampai penelitian dilakukan, peneliti belum menemukan adanya upaya yang dilakukan Puskesmas $X$ untuk mengubah sistem akuntansi yang mereka gunakan. Ketiadaan upaya mengubah sistem akuntansi terlihat dari Puskesmas X belum mempersiapkan dokumen-dokumen teknis persyaratan menjadi BLUD yang isinya terdiri dari laporan keuangan berupa neraca, laporan realisasi anggaran, dan catatan atas laporan keuangan.

Perubahan-perubahan yang akan terjadi pada akuntansi Puskesmas $\mathrm{X}$ terkait dengan perubahan akuntansi berbasis kas menjadi akuntansi berbasis akrual yaitu 1) Puskesmas $X$ akan mengakui pendapatan, biaya, asset, kewajiban, dan ekuitas; 2) Puskesmas $X$ akan merancang kebijakan akuntansinya sendiri untuk mengakui mengukur, menyajikan, dan mengungkapkan aset, kewajiban, dan ekuitas; dan 3) Puskesmas X akan membuat laporan keuangan tersendiri seperti neraca, laporan operasional, laporan arus kas, dan catatan atas laporan keuangan (Permendagri No. 61 Tahun 2007). Tidak hanya perubahan basis akuntansinya, Puskesmas X juga akan dituntut untuk membuat dua laporan keuangan dengan versi Standar Akuntansi Keuangan (SAK) dan versi Standar Akuntansi Pemerintahan (SAP) untuk kepentingan konsolidasian (Permendagri No 61 Tahun 2007) dengan Dinas Kesehatan Kabupaten Malang karena Puskesmas X meskipun nantinya sudah BLUD masih merupakan satu kesatuan dengan Dinas Kesehatan Kabupaten Malang.

Temuan bahwa Puskesmas X selama ini masih menggunakan sistem akuntansi berbasis kas padahal Pemerintahan Kabupaten Malang sejak tahun 2015 secara bertahap sudah beralih menuju sistem akuntansi berbasis akrual dapat juga menunjukkan bahwa selama ini Puskesmas X tidak diperkenalkan pada sistem akuntansi berbasis akrual meskipun Puskesmas X merupakan unit kerja 
di bawah Dinas Kesehatan Kabupaten Malang. Hal ini tentunya dapat menghambat rencana perubahan Puskesmas X menjadi BLUD dan kemungkinan penerapannya akan mundur dari target yang ditetapkan oleh Dinas Kesehatan. Penerapan akuntansi berbasis akrual memerlukan waktu yang tidak sedikit (Mulyana, 2009) karena sistem akuntansi berbasis akrual sangat kompleks dan sukar untuk dipahami oleh orang yang tidak memiliki keahlian khusus di bidangnya. Oleh karena itu, Puskesmas $\mathrm{X}$ setidaknya membutuhkan peran akuntan untuk membantunya dalam mempersiapkan diri menjadi BLUD. Guna mempersiapkan Puskesmas X menjadi BLUD, salah satu persyaratan teknis yang harus dipenuhi adalah laporan keuangan berupa neraca, laporan realisasi anggaran, dan catatan atas laporan keuangan (Permendagri No. 61 Tahun 2007).

\title{
c. Penerimaan Versus Penolakan
}

Perubahan organisasi dapat ditanggapi oleh aktor organisasi dengan dua cara yaitu menerima atau melawan (Wittig, 2012). Untuk mengetahui apakah aktor organisasi menerima atau melawan perubahan, agen perubahan harus memahami dengan benar definisi tanggapan terhadap perubahan (reaction to change) (Wittig, 2012). Menurut Oreg (dalam Wittig, 2012), tanggapan terhadap perubahan (reaction to change) merupakan sikap multidimensi terhadap perubahan yang terdiri dari perasaan terhadap perubahan (afektif), evaluasi nilai dan manfaat perubahan (kognitif), dan niat bertindak terhadap perubahan (komponen perilaku). Setiap dimensi tersebut dapat menggambarkan reaksi mulai dari penerimaan sampai penolakan terhadap perubahan (Wittig, 2012). Jika tiga dimensi ini dipertimbangkan secara keseluruhan, hasilnya akan menunjukkan penerimaan atau penolakan terhadap perubahan (Wittig, 2012).

Berdasarkan konsep di atas, Kepala Puskesmas X tergolong sebagai aktor yang menerima perubahan Puskesmas X menjadi BLUD karena pernyataan-pernyataan Kepala Puskesmas X menunjukkan aspek perilaku, aspek kognitif dan aspek afektif dari multidimensi sikap penentu individu menerima atau menolak/melawan perubahan. Komitmen Kepala Puskesmas X untuk tetap fokus mengutamakan pelayanan kesehatan daripada mengejar pendapatan menunjukkan aspek perilaku yang positif. Dengan kata lain, tindakan yang akan diambil Kepala Puskesmas X ketika Puskesmas $\mathrm{X}$ berubah menjadi BLUD akan mendukung proses perubahan tersebut. Komitmen Kepala Puskesmas X yang menunjukkan aspek perilaku yang positif tersebut terlihat pada pernyataan berikut ini.

\begin{abstract}
"Kalau kita ini sebenarnya lebih mengutamakan pelayanan. Hasil itu efek samping ya karena kalau pelayanannya baik, masyarakat itu banyak memanfaatkan maka secara otomatis finansialnya akan naik. Itu hukum yang gak tertulis begitu kan ya. Jadi, mereka yang utama pelayanan. Kalau pelayanan baik, mereka yang jauh misalnya "saya rawat inap di Bululawang saja". Kalau mengejar uang, itu jadinya kedodoran di pelayanan. Mengapa kita tidak mengejar pelayanan saja? Secara otomatis pelayanan yang baik akan mendatangkan. Secara otomatis begitu”. (BL. 24)
\end{abstract}

Di sisi lain, Kepala Puskesmas X juga menyatakan dukungannya terhadap perubahan dengan bersemangat. Pernyataan dukungan Kepala Puskesmas $X$ tersebut adalah sebagai berikut "Mendukung aja, ya asal ya itu tadi tidak $100 \%$ artinya biaya sendiri tapi untuk kebutuhankebutuhan yang besar perlu subsidi masih" (BL. 20). Dukungan terhadap perubahan yang disampaikan dengan bersemangat oleh Kepala Puskesmas X sekaligus menunjukkan aspek afektif dari multidimensi sikap penentu individu menerima atau menolak perubahan. Selain menyatakan dukungan, Kepala Puskesmas X memperlihatkan aspek kognisi dari multidimensi sikap penentu individu menerima atau menolak perubahan melalui pernyataan "...dengan BLUD jelas itu pelayanan harus baik. Dengan pelayanan yang baik, kemudian inovasi yang baik, masyarakat akan terlayani dengan baik ..." (BL. 1). Dari pernyataan tersebut, Kepala Puskesmas mempertimbangkan bahwa BLUD akan memberikan manfaat/berdampak baik pada pelayanan kesehatan masyarakat melalui inovasi-inovasi pelayanan kesehatan yang diusung BLUD. 
Sama halnya dengan Kepala Puskesmas X, Dokter Puskesmas X juga dapat digolongkan sebagai aktor yang menerima perubahan karena memenuhi aspek-aspek multidimensi sikap penentu individu menerima atau menolak perubahan. Dokter Puskesmas X menyatakan dukungannya terhadap perubahan Puskesmas X menjadi BLUD dengan lugas melalui pernyataan berikut "Ya mendukung saja ya." (BL. 20). Kelugasan Dokter Puskesmas X dalam menyatakan dukungannya menunjukkan bahwa Dokter Puskesmas X memiliki kemauan kuat untuk menjalani proses perubahan. Hal ini sekaligus merujuk pada aspek afektif/perasaan positif multidimensi sikap penentu individu menerima atau menolak perubahan. Dokter Puskesmas $\mathrm{X}$ mampu mempertimbangkan manfaat yang akan didapat dari perubahan Puskesmas X menjadi BLUD yang tercermin dari pernyataan berikut "Saya rasa BLUD lebih menguntungkan ya daripada status biasa." (BL. 23) serta "Ya jadi akan ada banyak inovasi nantinya kalau puskesmas ini berubah jadi BLUD. Banyak hal yang akan menguntungkan masyarakat" (BL. 20). Pernyataan-pernyataan Dokter Puskesmas X tersebut merujuk pada aspek kognitif salah satu multidimensi sikap penentu individu menerima atau menolak perubahan. Dokter Puskesmas $\mathrm{X}$ berkomitmen untuk meningkatkan kinerjanya jika Puskesmas X menjadi BLUD yang tercermin dari pernyataan berikut "Emm saya Insyaallah menyanggupi (meningkatkan kinerja jika nanti Puskesmas X jadi BLUD), karena saya yakin mungkin dengan adanya nanti inovasi-inovasi baru jika puskesmas ini berubah jadi BLUD, saya yakin tenaga juga akan ditambah.” (BL. 24). Dari pernyataan komitmen tersebut dapat dikatakan bahwa Dokter Puskesmas X akan mengambil tindakan positif dalam menyikapi perubahan. Pernyataan komitmen untuk meningkatkan kinerja tersebut sekaligus merujuk pada aspek perilaku salah satu penentu individu menerima atau menolak perubahan.

Bendahara Kapitasi/Bendahara Keuangan Pembantu/Bendahara Umum dan Bendahara BOK dapat digolongkan sebagai aktor yang menolak perubahan Puskesmas X menjadi BLUD. Bendahara Kapitasi/Bendahara Keuangan Pembantu/Bendahara Umum dan Bendahara BOK menyikapi rencana perubahan Puskesmas X menjadi BLUD secara enggan dan apatis. Keengganan yang ditunjukkan Bendahara Kapitasi/Bendahara Keuangan Pembantu/Bendahara Umum dapat dilihat dari pernyataan berikut ini.

...Saya nek melihat (pengelolaan keuangan BLUD) seperti itu kayak e, temen-temen (dari puskesmas BLUD) itu katanya lebih segala macem ya. Kayaknya saya gak kuat, kecuali kalau cuma megang satu saja mbak ya. Mungkin masih, saya masih kuat. Lha ini operasional (dana retribusi), saya, kapitasi saya, gaji saya, trus bendahara umum ya saya. Sek bidan desa barang. Mungkin kalau pegang salah satu sek iso, bisa menangani. (BL. 23)

Sedangkan sikap apatis yang ditunjukkan oleh Bendahara BOK dapat dilihat dari pernyataan "Kalo saya sih sak sak anunya (seadanya) aja gitu lho, nanti malah semakin ribet atau apa. Saya yang penting, lek maksudnya gak nambah-nambah anu (kerjaan) yo gak masalah.” (BL. 23). Kengganan dan apatisme para Bendahara Puskesmas X tersebut menujukkan aspek afektif, salah satu multidimensi sikap penentu individu menerima atau menolak perubahan. Dengan kata lain, para Bendahara Puskesmas X menunjukkan perasaan ketidaksukaannya terhadap perubahan Puskesmas $\mathrm{X}$ menjadi BLUD.

Perlawanan atau penolakan Bendahara Kapitasi/Bendahara Keuangan Pembantu/Bendahara Umum dipertegas lewat pernyataan "Setuju, tapi saya harus berhenti (sambil tertawa)" (BL. 20) dan "Makane nanti lek sini BLUD, saya mengeluarkan diri" (BL. 23). Pernyataan tersebut mewakili aspek perilaku, salah satu sikap multidimensional penentu individu melawan atau menerima perubahan, karena menunjukkan tindakan yang akan diambil oleh Bendahara Umum ketika perubahan BLUD terjadi. Perlawanan atau penolakan Bendahara BOK dipertegas melalui pernyataan "Gak tau untungnya apa, terus untungnya ke karyawan bagaimana. Kalau aku sih gitu. Lek aku. Karena tidak berpengaruh lek menurut saya, ya" (BL. 22). Pernyataan tersebut mewakili komponen kognitif, salah satu sikap multidimensional penentu seseorang melawan atau menerima perubahan, karena pernyataan tersebut menunjukkan bahwa Bendahara BOK mempertimbangkan keuntungan atau kerugian yang didapatnya jika Puskesmas $\mathrm{X}$ berubah menjadi BLUD . 
Feldman (dalam Baker, 1989) mengemukakan bahwa perlawanan pegawai terhadap perubahan dapat berupa penghindaran atau penundaan tugas, ketidaksukaan terhadap perubahan, baik yang dinyatakan secara verbal maupun tidak secara verbal, seperti pengunduran diri dari pekerjaan dan underproduction. Perlawanan pegawai terhadap perubahan juga dapat berupa peningkatan ketidakhadiran pegawai, peningkatan ketidaksabaran pegawai, frustasi, dan sabotase (Veaner dan Plate \& Stone dalam Baker, 1989). Jadi, karyawan dapat dikatakan melawan atau menolak perubahan jika menunjukkan salah satu atau beberapa perilaku yang disebutkan oleh Feldman (dalam Baker, 1989) dan Veaner, dkk (dalam Baker, 1989). Hal ini sekaligus mempertegas bahwa Bendahara Umum/Bendahara Kapitasi/Bendahara Keuangan Pembantu dan Bendahara BOK menolak/melawan perubahan Puskesmas X menjadi BLUD.

Berdasarkan pernyataan Feldman (dalam Baker, 1989) di atas, Bendahara Umum/Bendahara Kapitasi/Bendahara Keuangan Pembantu menunjukkan tanda perlawanan/penolakan terhadap perubahan ${ }^{1}$ yaitu pengunduran diri dalam pernyataan “...jadi, kan selama ini kan belum BLUD a. Saya cuma melihat katanya bendahara-bendahara itu kalau BLUD laporane tambah njelimet. Makane nanti lek sini BLUD, saya mengeluarkan diri." (BL. 23). Berbeda dengan Bendahara Umum/Bendahara Kapitasi/Bendahara Keuangan Pembantu, Bendahara BOK justru menunjukkan tanda penolakan/perlawanan terhadap perubahan melalui pernyataan ketidaksukaannya terhadap perubahan berikut ini

"Setuju apa enggak ya? Enggak tau yo mbak yo apa ya..... (merenung). Engga tau ya (tersela pembicaraan orang lain). Pasalnya gini lho mbak, opo lek terlalu akeh kerjaan gitu dengan adanya BLUD saya yo males juga. Kalau saya kan males saja lha wong gaji wong pns (pas-pasan) yo gitu kerjanya wes (banyak). Kalo saya sih sak sak anunya (seadanya) aja gitu lho, nanti malah semakin ribet atau apa. Saya yang penting, lek maksudnya gak nambah-nambah anu (kerjaan) yo gak masalah. He'eh. Terserah. Gak tau untungnya apa, terus untungnya ke karyawan bagaimana. Kalau aku sih gitu. Lek aku. Karena tidak berpengaruh lek menurut saya, ya gak tau lagi bagi orang lain ya." (BL. 22, BL. 23, BL. 24).

Terkait dengan perbedaan tanggapan para aktor Puskesmas $\mathrm{X}$ mengenai perubahan Puskesmas X menjadi BLUD, ada yang menerima dan ada yang menolak, hal ini dipengaruhi beberapa faktor. Faktor utama penyebab adanya perbedaan tanggapan para aktor adalah perubahan Puskesmas X menjadi BLUD ada yang berdampak langsung pada pekerjaan para aktor tetapi tidak berdampak langsung pada pekerjaan aktor yang lain. Para bendahara yang menolak perubahan Puskesmas X menjadi Badan Layanan Umum Daerah (BLUD) merupakan aktor yang terdampak langsung oleh perubahan tersebut, sedangkan perubahan tersebut tidak berdampak langsung bagi pekerjaan Kepala Puskesmas X dan Dokter Puskesmas X.

Para bendahara Puskesmas X kesehariannya menangani mulai dari pengumpulan bukti transaksi keuangan, kemudian mencatat atau membukukan transaksi keuangan, sampai melaporkan keuangan Puskesmas X ke Dinas Kesehatan Kabupaten Malang. Seperti yang telah dijelaskan sebelumnya, perubahan instansi pemerintah menjadi BLUD akan merubah juga sistem perakuntansian instansi tersebut. Perakuntansian pada Puskesmas X nantinya jika menjadi Badan Layanan Umum Daerah (BLUD) adalah penggunaan akuntansi berbasis akrual untuk mengakui pendapatan, biaya, aset, kewajiban dan ekuitas (Permendagri No. 61 Tahun 2007 tentang Teknis Badan Layanan Umum Daerah) sehingga Puskesmas X wajib membuat neraca, laporan operasional, laporan arus kas, dan catatan atas laporan keuangan. Dampaknya, para bendahara Puskesmas $\mathrm{X}$ akan dihadapkan pada pekerjaan/tugas yang benar-benar berbeda dengan pekerjaan sebelumnya.

Para bendahara Puskesmas X, yang saat ini terbiasa hanya mengakui/mencatat transaksi penerimaan dan pengeluaran saja, akan dihadapkan pada pengakuan/pencatatan aset, kewajiban,

\footnotetext{
${ }^{1}$ Aktor yang menolak/melawan perubahan salah satunya memiliki latar belakang sarjana gizi, sedangkan yang satunya lagi merupakan lulusan diploma kebidanan.
} 
ekuitas. Para bendahara Puskesmas X, yang terbiasa menunda mencatat atau membukukan transaksi, dituntut untuk melakukan pencatatan atau pembukuan tepat setelah transaksi keuangan terjadi. Para bendahara Puskesmas X yang terbiasa dengan pembukuan transaksi yang sederhana, akan dihadapkan pada pembuatan jurnal umum dan pencatatan double entry. Para bendahara yang biasanya hanya melaporkan SPJ, bukti transaksi, dan buku-buku keuangan, akan dihadapkan pada pembuatan laporan keuangan seperti neraca, laporan kinerja anggaran, laporan arus kas, dan catatan atas laporan keuangan. Selain itu, tugas/pekerjaan para bendahara pun akan bertambah dengan pembuatan laporan keuangan dua versi, yaitu versi SAK dan SAP, dan komputerisasi akuntansi melalui software E-medika sebagai bagian dari inovasi pelayanan.

Bendahara keuangan Puskesmas $\mathrm{X}$ yang tidak memiliki dasar pengetahuan akuntansi merasa terbebani dengan penggunaan akuntansi berbasis akrual termasuk dalam pembukuan dan pelaporan keuangan Puskesmas X. Dengan kata lain, para bendahara Puskesmas X merasa takut atau gelisah akan perubahan Puskesmas X menjadi BLUD yang akan berdampak langsung pada pekerjaannya sehingga para bendahara keuangan Puskesmas X lebih menolak/melawan rencana perubahan Puskesmas X menjadi BLUD. Perilaku Bendahara Puskesmas X ini mencerminkan pernyataan Morris \& Rabben (dalam Chuang, 2000) bahwa perlawanan/penolakan terhadap perubahan muncul akibat perubahan meningkatkan ketakutan atau kegelisahan tentang dampak nyata maupun dampak yang diimajinasikan yang dihasilkan oleh perubahan. Lebih lanjut lagi, Ketakutan yang ditunjukkan oleh kedua Bendahara Puskesmas X merupakan ketakutan yang disebabkan oleh creation of burden, perubahan menambah beban pekerjaan (Chuang, 2000). Pengunduran diri dari pekerjaan seperti yang disebutkan oleh Feldman (dalam Baker, 1989) merupakan salah satu jenis perlawanan pegawai terhadap perubahan. Pegawai cenderung melawan adanya perubahan karena mereka takut akan hal yang tidak dikenalnya (Baker, 1989).

Di sisi lain, Perubahan Puskesmas $X$ menjadi BLUD terutama dari segi perubahan akuntansi tidak akan berdampak apa pun pada pekerjaan dokter Puskesmas X dan Kepala Puskesmas X setiap harinya karena pekerjaan mereka setiap hari tidak ada sangkut pautnya dengan keuangan Puskesmas X. Pekerjaan dokter Puskesmas X setiap harinya adalah memberikan pelayanan kepada pasien, baik pelayanan berupa tindakan atau pemeriksaan. Sementara itu, Kepala Puskesmas X setiap harinya berurusan dengan urusan strategis Puskesmas X. Perubahan Puskesmas X menjadi BLUD dari segi perubahan pelayanan justru berdampak pada pekerjaan Dokter Puskesmas X dan Kepala Puskesmas. Dokter Puskesmas X terdampak perubahan pelayanan karena merupakan pihak yang menyampaikan pelayanan kepada pasien. Inovasi pelayanan sebagai bentuk perbaikan pelayanan, hanya akan mempermudah pekerjaan mereka. Kepala Puskesmas X terdampak perubahan pelayanan karena merupakan pihak yang mencari strategi untuk perubahan pelayanan dan mengambil keputusan perubahan pelayanan.

Faktor lain yang mempengaruhi perbedaan tanggapan para aktor terhadap perubahan Puskesmas X manjadi BLUD adalah manfaat dari perubahan akuntansi tidak dapat dirasakan langsung oleh pihak-pihak terkait, terutama oleh pihak yang pekerjaannya mengelola keuangan Puskesmas X. Sementara itu, manfaat dari perubahan pelayanan justru lebih dapat dirasakan langsung oleh pihak-pihak terkait, seperti manfaat komputerisasi pelayanan. Manfaat komputerisasi pelayanan yang sudah terasa dan terlihat oleh para aktor yaitu berkurangnya jumlah antrian di Puskesmas X dan proses pelayanan kesehatan menjadi lebih cepat. Oleh karena itu, para bendahara sebagai pihak pengelola keuangan Puskesmas X cenderung menolak perubahan Puskesmas X menjadi BLUD, sedangkan Kepala Puskesmas X dan Dokter Puskesmas X cenderung menerima perubahan puskesmas X menjadi BLUD.

Jika dikaji lebih dalam, pada kasus Puskesmas $\mathrm{X}$ ini, faktor komunikasi juga mempengaruhi aktor Puskesmas $\mathrm{X}$ dalam menanggapi atau menyikapi perubahan Puskesmas $\mathrm{X}$ menjadi BLUD. Seperti yang telah dijelaskan sebelumnya, Kepala Puskesmas X dan Dokter Umum Puskesmas $\mathrm{X}$ tergolong sebagai pihak yang menerima rencana perubahan Puskesmas X menjadi BLUD. Kedua aktor tersebut memiliki pengetahuan tentang BLUD. Kepala Puskesmas X merupakan pihak yang paham dengan baik mengenai rencana perubahan Puskesmas X menjadi 
BLUD karena merupakan kepanjangantangan dari Dinas Kesehatan Kabupaten Malang², sedangkan Dokter Umum Puskesmas X sebelumnya tahu tentang BLUD dan rencana Puskesmas menjadi BLUD karena menyimak sesi wawancara peneliti dengan Kepala Puskesmas. Dengan kata lain, rencana perubahan organisasi Puskesmas X telah dikomunikasikan kepada Kepala Puskesmas $\mathrm{X}$ dan Dokter Umum Puskesmas X. Oleh karena itu, kedua aktor ini mampu melihat besarnya manfaat perubahan Puskesmas X menjadi BLUD yang akan didapat/dirasakan tidak hanya dirinya sendiri tetapi juga pihak-pihak lain dibandingkan dengan kerugian yang akan dirasakan.

Di sisi lain, Bendahara Umum/Bendahara Kapitasi/Bendahara Keuangan Pembantu dan Bendahara BOK kurang informasi mengenai perubahan Puskesmas X menjadi BLUD yang artinya tidak ada pengkomunikasian mengenai BLUD kepada mereka. Kurangnya informasi mengenai rencanan perubahan Puskesmas X menjadi BLUD terlihat dari pernyataan Bendahara Umum/Bendahara Kapitasi/Bendahara Keuangan Pembantu "Aku belum paham blas ini. Takut aku, gak berani aku"(BL. 6) dan pernyataan Bendahara BOK "Nggak ngerti mbak aku (tertawa) keuntungannya apa ya anunya apa, nggak ngerti, nggak tau apa maksudnya (BLUD) apa itu nggak ngerti" (BL. 6). Oleh karena itu, kedua aktor ini hanya mampu mempertimbangkan dampak perubahan Puskesmas X pada pekerjaan mereka saja, sehingga pada akhirnya mereka menolak/melawan rencana perubahan Puskesmas $X$ menjadi BLUD. Hal ini sesuai dengan pendapat Baker (1989) tentang pihak yang diberi informasi dengan jelas tentang bagaimana perubahan organisasi secara langsung berdampak pada pekerjaannya, akan menerima perubahan tersebut secara signifikan daripada mereka yang tidak diberi informasi (Baker, 1989).

Dari pembahasan di atas, dapat diketahui bahwa di Puskesmas X tidak hanya ada aktor menerima, tetapi ada aktor yang melawan/menolak rencana perubahan Puskesmas X menjadi BLUD. Elving (dalam Husain, 2013) menyatakan bahwa tingkat perlawanan yang rendah terhadap perubahan akan berdampak pada implementasi perubahan organisasi yang efektif dan berlaku sebaliknya. Mengingat banyak aktor Puskesmas X lainnya yang tidak ikut ditanyai tentang tanggapan mereka, ada kemungkinan bahwa aktor-aktor yang tidak ikut menjadi narasumber akan menunjukkan ketakutan yang sama atau gejala perlawanan lainnya. Untuk menghindari kemungkinan munculnya tindakan perlawan terhadap perubahan oleh aktor-aktor Puskesmas X yang lain dan demi kesuksesan penerapan perubahan BLUD di Puskesmas X, Dinas Kesehatan Kabupaten Malang sebagai agen perubahan dapat mengikuti saran yang diajukan Baker (1989) untuk mengurangi ketakutan pegawai akan perubahan organisasi.

Cara yang dapat dilakukan untuk mengurangi ketakutan pegawai terhadap perubahan (Baker, 1989) adalah 1) manajemen harus menyediakan sebanyak mungkin informasi aktual tentang perubahan, 2) manajemen harus menginformasikan secara jelas alasan mengapa perubahan dilakukan kepada pegawai, 3) manajemen harus melakukan semua hal yang mungkin dapat dilakukan untuk memberi penjelasan atas pertanyaan yang diajukan pegawai tentang perubahan, dan 4) manajemen harus memberikan kesempatan bagi pegawai untuk merenungkan kemungkinan dampak perubahan bagi mereka sendiri, dampak perubahan bagi organisasi secara keseluruhan dan dampak perubahan bagi pelanggan (konsumen). Menurut Werbel, Weinbach, dan Malinconico (dalam Baker, 1989), pegawai akan merespon perubahan lebih baik apabila manajemen berinisiatif untuk mengurangi ketakutan mereka.

Dinas Kesehatan Kabupaten Malang sebagai agen perubahan juga dapat mengadopsi metode-metode yang ditawarkan oleh Erkmen (2006) untuk menanggulangi perlawanan terhadap perubahan. Metode-metode yang ditawarkan oleh Erkmen (2006), yaitu 1) memberikan pelatihan pegawai mengenai manfaat dan hasil dari perubahan tersebut, 2) membiarkan pegawai berpartisipasi dalam proses perubahan sejak awal dengan gagasan dan saran mereka, 3) berdiskusi dan bernegosiasi mengenai masalah, keuntungan finansial atau keuntungan lainnya yang akan didapat oleh pihak-pihak yang terkait sebagai hasil dari perubahan, dan 4) memfasilitasi keadaan dengan memberikan yang dibutuhkan. Metode yang ditawarkan oleh Baker (1989) lebih berfokus

${ }^{2}$ Kepala Puskesmas merupakan Birokrat. Birokrat akan cenderung menerima perubahan sebagai kebijakan atasananya. 
pada komunikasi, sedangkan metode yang ditawarkan oleh Erkmen (2006) lebih menekankan pada aksi.

\section{SIMPULAN DAN SARAN}

Berdasarkan hasil pembahasan maka dapat disimpulkan bahwa aktor yang tidak berhubungan langsung dengan pelaporan keuangan cenderung menerima BLUD, sedangkan aktor yang terlibat langsung dengan pelaporan keuangan cenderung menolak BLUD. Aktor yang menerima BLUD adalah dokter (paramedis) dan Kepala Puskesmas X (Pimpinan). Aktor yang menolak BLUD merupakan bendahara kapitasi/bendahara keuangan pembantu/bendahara umum Puskesmas X dan Bendahara BOK, dimana setiap harinya bersinggungan langsung dengan laporan keuangan. Dapat dikatakan bahwa yang paling berdampak dengan berubahnya Puskesmas $\mathrm{X}$ menjadi BLUD adalah para bendahara karena BLUD lebih banyak mengubah pola sistem perakuntansian suatu organisasi ketika organisasi berubah menjadi BLUD.

Dinas Kesehatan sebagai agen perubahan hendaknya segera menangani dan mencegah penolakan/perlawanan terhadap rencana perubahan organisasi Puskesmas X melalui komunikasi dan aksi. Puskesmas $\mathrm{X}$ hendaknya juga memberi pelatihan para bendaharanya mengenai akuntansi BLUD dan merekrut akuntan untuk mempercepat proses perubahan sistem anggaran dan sistem akuntansi Puskesmas.

Kontribusi teoritis hasil penelitian adalah memperkaya kajian teori NPM dalam konteks organisasi kesehatan terutama Puskesmas. Kontribusi praktis dari hasil penelitian sebagai masukan bagi instansi terkait, yaitu Puskesmas dan Dinas Kesehatan untuk memahami dan mengevaluasi beban kerja bagian akuntansi yang paling berdampak atas perubahan BLUD. Hal ini sebagai dasar untuk pembuatan kebijakan beban kerja dan kompensasi pegawai.

\section{DAFTAR RUJUKAN}

Adah, A. \& Mamman, A. 2013. Assesing the Performance of Incremental Budgeting System in the Nigerian Public Tertiary Institutions. European Journal of Business and Management, (Online), 5 (5): 100-108, (www.iiste.org), diakses Juni 2017.

Anggraeny, C. 2013. Inovasi Pelayanan Kesehatan dalam Meningkatkan Kualitas Pelayanan di Puskesmas Jagir Kota Surabaya. Kebijakan \& Manajemen Publik, 1 (1): 85-93.

Anugrah. 7 April 2016. Hanya di Kabupaten Malang, Puskesmas Buka 24 Jam. Harian Terbit. (Online), (http://www.harianterbit.com/hanterdaerah/read/2016/04/07/59616/81/20/Hanyadi-Kabupaten-Malang-Puskesmas-Buka-24-Jam).

Ariyati, R., Pinasti, M., dan Putri, N.K. 2016. Penerapan Standar Akuntansi Keuangan (SAK) dan Standar Akuntansi Pemerintahan (SAP) pada Sistem Akuntansi Badan Layanan Umum Universitas. Makalah disajikan dalam Simposium Nasional Akuntansi XIX, Lampung, 2016.

Baker, S.L. 1989. Managing Resistance to Change. Library Trends, (Online), 38 (1): 53-61, (https://www.ideals.illinois.edu/bitstream/handle/2142/7649/librarytrendsv38i1h_opt.pdf), diakses Mei 2017.

Blöndal, J.R. 2003. Accrual Accounting and Budgeting: Key Issues and Recent Developments. OECD Journal on Budgeting, (Online), 3 (1): 43-59, (https://www.oecd.org/gov/budgeting/42187847.pdf), diakes Juni 2017.

Bojović, V. 2006. Public Private Partnership as a Last Resort for Traditional Public Procurement. Panoeconomicus, (Online), 53 (3): 299-311, (www.doiserbia.nb.rs/ft.aspx?id=1452595X0603299B), diakses Mei 2017.

Chuang, Y.S. 2000. Individual Resistance from Employees to Change. The Journal of Global
Bussiness
Management,
(Online),
2 (3):
19-24, (http://www.jgbm.org/page/19\%20Dr.\%20Chuang,Yuh-Shy.pdf), diakses Mei 2017. 
Direktorat Inovasi dan Inkubator Universitasi Indonesia. 2016. Inovasi. Makalah disajikan dalam Innovaction UI 2016 Worksop, Jakarta, 7 September.

Engström, J. 2014. Patient Involvement and Service Innovation in Healthcare. Disertasi diterbitkan. Linköping-Swedia: LiU-Tryck.

Erkmen, T. 2006. A Study about Employees' Acceptance of Change: Practices in Organizations. Yönetim Yil, 55 (17): 1-15.

Fonseca, T. 2014. Combining Product and Process Innovation: is Organizational Innovation the Crucial Complement?. Economics, 24 (4): 557-579.

Hansen, M. B. 2009. The Impact of Organizational Innovations NPM and ICT in the Field of Social Policy. European Consortium of Political Research (ECPR) Joint Sessions of Workshops, Rennes, France, 11-16 April 2009.

Hassan, M. M. 2013. Debates on Accrual Accounting in the Public Sector: A Discrepancy Between Practitioner and Academicians. Prosiding disajikan pada Seventh Asia Pacific Interdisciplinary Research in Accounting Conference-APIRA, Kobe, Juli.

Hood, C. 1991. A Public Management for All Seasons. Public Administration, (Online), 69: 3-19, (http://newdoc.nccu.edu.tw), diakses 5 Oktober 2016.

Husain, Z. 2013. Effective Communication Brings Successful Organizational Change. The Bussiness \& Management Review, 3 (2): 43-50.

Ibrahim, P. 2013. Akuntansi Akrual dan Penerapannya di Sektor Publik: Telaah Pustaka. Skripsi tidak diterbitkan. Fakultas Ekonomi dan Bisinis Universtitas Hasanuddin Makassar.

Indrawati, N. 2010. Penyusunan Anggaran dalam Era New Public Management: Implementasinya di Indonesia. Jurnal Riset Akuntansi dan Bisnis, (Online), 10 (2): 176-193, (http://jurnal.umsu.ac.id), diakses 6 Oktober 2016.

Kurrohman, T. 2013. Evaluasi Penganggaran Berbasis Kinerja Melalui Kinerja Keuangan yang Berbasis Value for Money di Kabupaten atau Kota di Jawa Timur. Jurnal Dinamika Akuntansi, 5 (1): 1-11.

Kuswarno, Engkus. 2009. Metodologi Penelitian Komunikasi Fenomenologi. Bandung: Widya Padjajaran.

Malmmose, M. 2012. The Role of Management Accounting in New Public Management Reforms: Implications in a Socio-Political Health Care Context. Tesis tidak diterbitkan. Department of Economic and Business Aarhus University-Denmark.

Mardiasmo. 2004. Otonomi dan Manajemen Keuangan Daerah. Yogyakarta: Andi.

Meidyawati. 2011. Analisis Implementasi Pola Pengelolaan Keuangan Badan Layanan Umum (PPK-BLU) pada Rumah Sakit Stroke Nasional Bukittinggi. Tesis tidak diterbitkan. Padang: Program Pascasarjana Universitas Andalas.

Mengubah Status Puskesmas Menjadi BLUD. Jaminan Sosial Indonesia. (Online), (http://jamsosindonesia.com), di akses 30 September 2016.

Mulyana, B. 2009.Penggunaan Akuntansi Akrual di Negara-negara Lain: Tren di Negara-negara Anggota OECD, (Online), (http://sutaryofe.staff.uns.ac.id/files/2011/10/akuntansberbasisakrual.pdf), diakses Juni 2017.

Pendukung Kesehatan LPPD Tahun 2015. Dinas Kesehatan Kabupaten Malang. (Online), (http://dinkes.malangkab.go.id), diakses 8 Oktober 2016.

Peraturan Bupati Malang No. 13 Tahun 2014 tentang Sistem Akuntansi Pemerintah Daerah Kabupaten Malang. Jaringan Data dan Informasi Hukum Kabupaten Malang, (Online), (http://jdih.malangkab.go.id), diakses Juni 2017.

Peraturan Menteri Dalam Negeri No. 64 Tahun 2013 tentang Penerapan Standar Akuntansi Pemerintahan Berbasis Akrual pada Pemerintah Daerah. Direktorat Jenderal Keuangan Daerah Kementerian Dalam Negeri, (http://keuda.kemendagri.go.id/produkhukum/bytahun/3/2013), diakses Juni 2017.

Peraturan Menteri Dalam Negeri Republik Indonesia No. 61 Tahun 2007 tentang Pedoman Teknis Pengelolaan Keuangan Badan Layanan Umum Daerah. Jaringan Dokumentasi dan 
Informasi Hukum Badan Pemeriksa Keuangan Republik Indonesia. (Online), (http://jdih.bpk.go.id), di akses 8 Oktober 2016).

Peraturan Pemerintah Republik Indonesia No 74 Tahun 2012 tentang Perubahan atas Peraturan Pemerintah Republik Indonesia No. 23 Tahun 2005 tentang Pengelolaan Keuangan Badan Layanan Umum Daerah. Jaringan Dokumentasi dan Informasi Hukum Kementerian Keuangan Republik Indonesia. (Online), (http://jdih.kemenkeu.go.id), diakses 6 Oktober 2016.

Peraturan Pemerintah Republik Indonesia No. 23 Tahun 2005 tentang Pengelolaan Keuangan Badan Layanan Umum. Direktorat Jenderal Perimbangan Keuangan Republik Indonesia. (Online), (http://djpk.depkeu.go.id), diakses 6 Oktober 2016.

Prakoso, C.T. 2014. Eksistensi Badan Layanan Umum Ditinjau dari Perspektif New Institutional dan Principal Agent Theory. eJournal Administratif Reform. (Online), 2 (4): 2422-2432.

Purmono, A. 11 November 2010. Puskesmas Berubah Jadi Badan Layanan Umum. Tempo. (Online), (https://m.tempo.co/read/news/2010/11/11/180291207/puskesmas-berubah-jadibadan-layanan-umum)

Rondonuwu, J. \& Trisnantoro, L. 2013. Manajemen Perubahan di Lembaga Pemerintah: Studi Kasus Implementasi Kebijakan Pelaksanaan PPK-BLUD di Rumah Sakit Jiwa Provinsi NTB. Jurnal Kebijakan Kesehatan Indonesia, 2 (4): 163-170.

Rohmawati, I. 2015. Pengaruh Penganggaran Berbasis Kinerja, Kejelasan Sasaran Anggaran, dan Partisipasi Anggaran terhadap Akuntabilitas Kinerja Aparat Pemerintahan Daerah. Skripsi tidak diterbitkan. Fakultas Ekonomi dan Bisnis Universitas Muhammadiyah Surakarta.

Sahin, I. 2006. Detailed Review of Rogers Diffussion of Innovations Theory \& Educational Technology-Related Studies Based on Roger's Theory. The Turkish Online Journal of Educational Technology, (Online), 5 (2): 14-23, (tojet.net/articles/v5i2/523.pdf),diakses Juli 2017.

Sugiyarti, G. 2015. Membangun Keunggulan Bersaing Produk Melalui Orientasi Pembelajaran, Orientasi Pasar, dan Inovasi Produk (Studi Empiris pada Industri Pakaian Jadi Skala Kecil dan Menengah di Kota Semarang. Serat Acitya, (Online), 4 (2): 110-123, (http://jurnal.untagsmg.ac.id/index.php/sa/article/view/157/215), diakses Mei 2017.

Sugiyono. 2010. Memahami Penelitian Kualitatif. Bandung: CV. ALFABETA.

Surabaya Bisnis. 7 Mei 2016. Malang Targetkan 39 Puskesmas Jadi Badan Layanan Umum Daerah. (Online), (http://surabaya.bisnis.com/read/20160507/4/88647/url), diakses 2 Oktober 2016).

Syarifuddin. 2003. Model-Model Anggaran pada Organisasi Sektor Publik dan Perkembangannya. Makalah disajikan dalam Seminar Bulanan Jurusan Akuntansi Fakultas Ekonomi Universitas Hasanuddin, Makassar, Agustus 2003.

The Budget Model Review Committee. 2014. White Paper: University of Wisconsin-Madison Budget Allocation-Past, Present, and Possibilities. University of Wisconsin-Madison.

Widyantoro, A. E. 2009. Implementasi Performance Based Budgeting: Sebuah Kajian Fenomenologis (Studi Kasus pada Universitas Diponegoro). Tesis tidak diterbitkan. Program Pascasarjana Universitas Diponegoro.

Wittig, C. 2012. Employees' Reactions to Organizational Change. OD Practitioner, (Online),44 (2): 23-28, (http://www.odnetwork.org/resource/resmgr/odp/odp-v44,no2-wittig.pdf), diakses Mei 2017.

Yin, Robert K. 1994. CASE STUDY RESEARCH. Thousand Oaks, London, New Delhi: SAGE Publications

Zamalludin. 2006. Analisis Model Penciptaan Nilai (Value Creation) dengan Mempertimbangkan Perbaikan Proses Bisnis untuk Meningkatkan Keunggulan Daya Saing Berkelanjutan di Pos Express PT Pos Indonesia. Skripsi tidak diterbitkan. Bandung: Fakultas Teknik Universitas Widyatama Bandung. 